\title{
POTENSI AKUMULASI ASAP CAIR PENGOLAHAN KELAPA DAN HASIL SAMPINGNYA
}

\section{POTENCY OF LIQUID SMOKE ACCUMULATION OF COCONUT AND ITS BY- PRODUCTS PROCESSING}

\author{
Broerie Pojoh \\ Balai Riset dan Standardisasi Industri Manado \\ Jalan Diponegoro No. 21-23 Manado \\ Pos-el: b_pojoh@yahoo.com
}

\begin{abstract}
ABSTRAK
Kelapa dan produk turunannya dimanfaatkan secara luas sebagai sumber minyak, makanan, minuman, bahan bakar, dan bahan bangunan. Terdapat kecenderungan semakin menurunnya produktivitas kelapa dan perannya bagi ekonomi masyarakat. Hal ini disebabkan oleh nilai jual yang relatif rendah dan berfluktuasi terutama terhadap produk utama yang dihasilkan, yaitu kopra asap. Upaya-upaya yang dilakukan untuk meningkatkan keekonomian kelapa dilakukan antara lain dengan mengusahakan diversifikasi usaha dengan tanaman sela atau perikanan/peternakan. Meningkatnya permintaan terhadap produk seperti VCO membangkitkan semangat bagi petani/pengolah kelapa untuk mengolah kelapa. Salah satu alternatif usaha yang dapat dilakukan untuk meningkatkan nilai tambah kelapa adalah dengan mengusahakan akumulasi asap cair dari proses pembuatan kopra asap/kopra putih, atau arang tempurung kelapa. Terdapat potensi yang sangat besar dari asap cair pada pengolahan kelapa menjadi kopra asap atau kopra putih serta pembuatan arang tempurung. Akumulasi asap cair pada pengolahan kelapa dapat dilakukan dengan menambahkan kondensor pada tungku pembuatan kopra putih Tipe Baristand Industri Manado dan tungku pembuatan arang tempurung tipe Behive Baristand Industri Manado. Alternatif lainnya dari penggunaan kondensor tersebut adalah dengan meneliti kemungkinan aplikasi teknik pendinginan yang diterapkan pada proses pembuatan minuman tradisional Minahasa, yaitu pembuatan cap tikus. Akumulasi asap menjadi asap cair setidaknya memberikan dua keuntungan, yaitu meningkatkan nilai tambah pengolahan kelapa menjadi produk yang bermanfaat dan menghindarkan pencemaran lingkungan akibat asap dari pengolahan kopra dan pembakaran arang tempurung.
\end{abstract}

Kata kunci: asap cair, kopra asap, kopra putih, sabut kelapa, arang tempurung

\begin{abstract}
Coconut and its derivatives are widely used as a source of oil, food, beverages, fuel, and building materials. There is a tendency for declining coconut productivity and its role for the economy of society. This is due to the relatively low selling value and fluctuates mainly to the main product produced, ie smoked copra. Efforts undertaken to improve the coconut economy are done, among others, by seeking to diversify the business with intercrops or fishery / livestock. Increased demand for products such as VCO evokes enthusiasm for farmers / coconut processors to cultivate coconuts. One of the alternative business that can be done to increase the added value of coconut is by seeking the accumulation of liquid smoke from the process of making smoked copra / white copra, or coconut shell charcoal. There is a huge potential of liquid smoke in the processing of coconut into smoked copra or white copra and the manufacture of shell charcoal. The accumulation of liquid smoke in the coconut processing can be done by adding condensers to the white copra making furnace of Balai Riset dan Standardisasi Industri Type and the Balai Riset dan Standardisasi Industri Behive Type for shell charcoal making. Another alternative to the use of condensers is to examine the possibility of application of cooling techniques applied to the process of making Minahasa traditional drinks, namely the manufacture of "cap tikus." The accumulation of smoke into liquid smoke at least provides two advantages, namely to increase the added value of coconut processing into a useful product and avoid environmental pollution due to smoke from copra processing and charcoal burning.

Keywords: liquid smoke, smoked copra, white copra, coconut husk, shell charcoal
\end{abstract}




\section{PENDAHULUAN}

Kelapa (Cocos nucifera L) dikenal sebagai pohon kehidupan (tree of life) untuk perannya sebagai sumber mata pencaharian penting bagi banyak petani kecil. Di wilayah Sulawesi Bagian Utara, tanaman ini berperan sebagai peneduh bagi tanaman lain, sumber makanan dan minuman, serta bahan bakar ataupun bahan bangunan, kerajinan, kemasan, dan keperluan lain.

Berbeda dengan kelapa sawit, pemilikan lahan kelapa didominasi oleh petani kecil/rakyat. Data menunjukkan bahwa luasan areal tanaman kelapa di Provinsi Sulawesi Utara adalah 278.483 ha yang terdiri atas 268.561 ha perkebunan rakyat, 1.566 ha Perkebunan Negara, dan 8.356 ha Perkebunan Swasta, dengan total produksi 284.330 ton/tahun (1). Dibandingkan dengan daerah lain, provinsi ini adalah penghasil kelapa No. 2 di Indonesia setelah Riau, berubah dari statusnya di masa lalu sebagai penghasil kelapa utama sehingga dijuluki sebagai Daerah Nyiur Melambai. Penurunan luasan dan produksi lahan tersebut terjadi karena pemekaran wilayah (Kabupaten Gorontalo menjadi provinsi tersendiri) dan terutama karena konversi lahan kelapa ke penggunaan lain serta penurunan produktivitas kelapa karena penuaan umur tanaman kelapa.

Petani kecil umumnya menghasilkan produk kopra, kecuali untuk petani yang lokasi lahannya dekat dengan pabrik tepung kelapa atau perkotaan, juga sering menjual dalam bentuk biji utuh segar. Belakangan ini marak terjadi penjualan kelapa utuh segar untuk tujuan ekspor yang mengancam eksistensi industri pengolahan di dalam negeri, sehingga mulai diprotes kalangan asosiasi/ pengusaha kelapa dalam negeri. Sebagai contoh, Idroes, A. dari Himpunan Industri Pengolahan Kelapa Indonesia (HIPKI) menyatakan bahwa ekspor kelapa utuh akan semakin memperburuk pasokan kebutuhan kelapa industri pengolahan di Indonesia. Dari kebutuhan dalam negeri sekitar 14 milyar butir, yang terpenuhi kurang dari $50 \%$, dan untuk industri VCO dan santan sampai dengan 20 milyar butir segar, yang terpenuhi hanya $35-40 \%$ (2).

Data menunjukkan bahwa luasan pemilikan lahan kelapa Perkebunan Rakyat lebih kecil dari 1 ha/keluarga. Luasan kepemilikan ini akan cenderung terus mengecil disebabkan oleh sistem pewarisan lahan. Sistem ini membawa konsekuensi yang beragam, terutama semakin tidak menguntungkannya secara ekonomis pengusahaan tanaman kelapa karena faktor produktivitas yang menurun seiring dengan semakin tuanya tanaman kelapa sehingga pohon semakin tinggi dan semakin sulit dipanjat, dan skala usaha yang semakin kecil. Harga kopra dan minyak kelapa yang tidak menguntungkan dan berfluktuasi dan standar pasar yang meningkat seputar kualitas dan keamanan konsumen 
menyebabkan banyak pohon kelapa tidak dipanen. Hal ini menurunkan minat investasi atau penanaman/peremajaan kelapa dan mendorong petani atau pemilik lahan kelapa untuk cenderung kurang memperhatikan pemeliharaan tanaman kelapa atau cenderung untuk menjual lahan kepada pihak lain untuk konsolidasi lahan maupun untuk konversi penggunaan.

Salah satu upaya yang dilakukan oleh petani untuk mengantisipasi semakin tidak menguntungkannya usaha perkebunan kelapa adalah dengan melakukan pengusahaan tanaman sela, seperti cengkeh atau pala. Sebagai contoh, petani kelapa di Desa Tolombukan Kecamatan Pasan, Kabupaten Minahasa mengembangkan tanaman sela berupa cengkeh, yang justru berkontribusi sebesar 70,57\% dari pendapatan usahatani kelapa sebesar Rp 16.626.644 (3). Sejalan, Suratinojo (2) mendapatkan hasil penelitian yang menyatakan kontribusi usahatani kelapa di Kecamatah Kauditan, Kabupaten Minahasa Utara, yaitu sebesar 16,8\% dan non-kelapa sebesar $57,3 \%$.

Kemunculan teknik pengolahan modern untuk menghasilkan Virgin Coconut Oil (VCO) sebagai produk kesehatan dan farmasi memberi harapan baru dan menghidupkan kembali minat untuk memelihara tanaman kelapa, yang bertumpu pada petani kecil dan pengolahan rumah tangga/industri mikro (4). Hasil-hasil kajian di beberapa wilayah menunjukkan bahwa peningkatan pendapatan petani kelapa dapat dilakukan disamping melalui tanaman sela, pengusahaan ternak, atau perikanan, juga dengan melakukan pengolahan secara terpadu terhadap kelapa dan turunannya serta hasil sampingnya (4).

Sebagaimana yang terjadi di banyak negara-negara penghasil kelapa di Asia Pasifik, pertanaman kelapa di wilayah ini juga relatif semakin tua dan pohonnya semakin tinggi, dilain pihak produktivitas kelapa semakin menurun (5). Kondisi yang bertolak belakang tersebut menyebabkan usaha pertanaman kelapa semakin kurang menguntungkan bagi petani kelapa karena meningkatnya biaya pengolahan kopra (pemanjatan, pengumpulan, pengangkutan, pengupasan, dan pengasapan). Data hasil wawancara dengan Umpel, W. (Ketua Asosiasi Petani Kelapa Sulut) (6) diketahui bahwa biaya pengolahan kopra di kebanyakan daerah di Sulawesi Utara sudah mencapai $50 \%$ dari harga jual kopra.

Usaha yang semakin kurang menguntungkan ini perlu diantisipasi dengan cara antara lain mengoptimalkan segala potensi yang ada dalam proses pengolahan kopra. Salah satu alternatif yang dapat dipertimbangkan adalah dengan melakukan modifikasi terhadap tungku pengasapan kopra yang memungkinkan diakumulasinya asap cair yang terbentuk saat pengasapan kopra berlangsung. Juga modifikasi terhadap tungku pembuatan arang tempurung 
sehingga asap yang terbentuk dapat dikonversi menjadi asap cair dan diakumulasikan. Asap cair tersebut selanjutnya dapat dijual oleh petani kelapa untuk meningkatkan pendapatan keluarga petani.

Tulisan ini bertujuan untuk membahas potensi akumulasi asap cair pada pengolahan kelapa menjadi kopra dan atau pengolahan hasil samping seperti sabut dan tempurung yang memiliki manfaat untuk pengawetan bahan pangan atau non-pangan untuk meningkatkan nilai tambah tanaman kelapa.

\section{POTENSI HASIL SAMPING KELAPA}

Rata-rata produksi buah kelapa di Indonesia adalah 16,35 milyar butir dari lahan dengan luasan 3,5 juta ha atau sebanyak 4.529 butir/ha/tahun. (5) Produktivitas kelapa di Indonesia Tahun 2014 adalah $1.136 \mathrm{~kg} / \mathrm{ha} \quad(1)$. Berdasarkan kalkulasi tersebut, produksi kelapa utuh di Sulawesi Utara Tahun 2016 dari 226.634 ha (1) tanaman kelapa yang menghasilkan, diperkirakan sebanyak 1,03 milyar butir.

Kelapa utuh dipanen pada saat umur buah mencapai 10-12 bulan. Kelapa utuh selanjutnya dikupas sehingga diperoleh hasil samping (byproducts) berupa sabut kelapa dan juga tempurung kelapa, Data yang dipublikasi oleh Rindengan yang dikutip oleh Mahmud (7) menunjukkan bahwa persentasi sabut dan tempurung terhadap berat kelapa adalah sebesar $56 \%$ dan $28 \%$.
Tempurung kelapa selama ini dijual dalam keadaan segar atau diarangkan untuk digunakan sebagai bahan bakar atau untuk pembuatan arang aktif. Sabut kelapa merupakan komponen yang voluminous dan kurang dimanfaatkan terutama apabila tempat pengolahan kopra terletak jauh dari perkampungan sehingga biasanya hanya digunakan sebagai bahan bakar pengolahan kopra atau dibiarkan membusuk di sekitar lahan pertanaman kelapa, yang dapat berperan sebagai pemasok bahan organik bagi lahan perkebunan, tapi sekaligus dapat menjadi sumber hama dan penyakit serta pencetus kebakaran lahan manakala menjadi kering.

Hasil penelitian yang dilakukan oleh Pojoh (8) menunjukkan bahwa potensi asap cair dari sabut kelapa adalah sekitar $200 \mathrm{ml}$ untuk setiap kilogram sabut kelapa (tergantung kadar air sabut kelapa). Dengan merujuk pada data tersebut, potensi asap cair di wilayah Sulawesi Bagian Utara yang menghasilkan kelapa sejumlah 1,03 milyar butir kelapa adalah 206 juta liter/tahun. Suatu jumlah yang sangat besar dan potensial menjadi sumber pendapatan baru bagi petani kelapa untuk meningkatkan pendapatan mereka karena adanya kegunaan dari asap cair bagi pengawetan bahan pangan dan non-pangan.

Potensi yang sangat besar juga dapat diperoleh dari proses pengolahan tempurung menjadi arang tempurung kelapa yang justru lebih banyak 
dipraktekkan di lapangan karena menghasilkan produk yang bernilai jual relatif tinggi. Salah satu keuntungan dari sistem pengolahan ini adalah pengendalian terhadap pencemaran udara yang diakibatkan oleh asap yang sangat mengganggu apabila proses produksi dilakukan di lokasi dekat permukiman penduduk atau di dekat jalan raya, seperti yang dipraktekkan di beberapa lokasi di Jalan Trans Sulawesi, Kabupaten Minahasa Selatan. Usaha untuk menghasilkan asap cair pada pembuatan arang tempurung secara terintegrasi juga sudah dilakukan oleh beberapa peneliti/pengusaha seperti oleh Samadi (9).

\section{ASAP CAIR PENGOLAHAN DAN HASIL SAMPING KELAPA}

Asap merupakan dispersi uap asap dalam udara, yang dihasilkan dari proses distilasi kering atau pirolisa biomasa seperti kayu, kulit kayu, tempurung, sabut, bambu, daun, dan lain sebagainya (Girrard, 1992). Adapun komponen-komponen penyusun asap cair meliputi:

\section{Senyawa-senyawa fenol}

Senyawa fenol diduga berperan sebagai antioksidan sehingga dapat memperpanjang masa simpan produk asapan. Kandungan senyawa fenol dalam asap sangat tergantung pada temperatur pirolisis kayu. Menurut Girard (1992) (11), kuantitas fenol pada kayu sangat bervariasi yaitu antara 10$200 \mathrm{mg} / \mathrm{kg}$. Beberapa jenis fenol yang biasanya terdapat dalam produk asapan adalah guaiakol, dan siringol. Senyawasenyawa fenol yang terdapat dalam asap kayu umumnya hidrokarbon aromatik yang tersusun dari cincin benzena dengan sejumlah gugus hidroksil yang terikat. Senyawasenyawa fenol ini juga dapat mengikat gugus-gugus lain seperti aldehid, keton, asam dan ester (Maga, 1987 dalam Darmadji (11)).

\section{Senyawa-senyawa karbonil}

Senyawa-senyawa karbonil dalam asap memiliki peranan pada pewarnaan dan citarasa produk asapan. Golongan senyawa ini mepunyai aroma seperti aroma karamel yang unik. Jenis senyawa karbonil yang terdapat dalam asap cair antara lain adalah vanilin dan siringaldehida.

\section{Senyawa-senyawa asam}

Senyawa-senyawa asam mempunyai peranan sebagai antibakteri dan membentuk citarasa produk asapan. Senyawa asam ini antara lain adalah asam asetat, propionat, butirat dan valerat.

\section{Senyawa hidrokarbon polisiklis aromatis}

Senyawa hidrokarbon polisiklis aromatis (HPA) dapat terbentuk pada proses pirolisis kayu. Senyawa hidrokarbon aromatik seperti benzo(a)pirena merupakan senyawa yang memiliki pengaruh buruk karena bersifat karsinogen (Girard, 1992) (11). Girard (1992) (11) menyatakan bahwa pembentukan berbagai senyawa HPA selama pembuatan asap tergantung dari 
beberapa hal, seperti temperatur pirolisis, waktu dan kelembaban udara pada proses pembuatan asap serta kandungan udara dalam kayu. Dikatakan juga bahwa semua proses yang menyebabkan terpisahnya partikelpartikel besar dari asap akan menurunkan kadar benzo(a)pirena. Proses tersebut antara lain adalah pengendapan dan penyaringan.

\section{Senyawa benzo(a)pirena}

Benzo(a)pirena mempunyai titik didih $310{ }^{\circ} \mathrm{C}$ dan dapat menyebabkan kanker kulit jika dioleskan langsung pada permukaan kulit. Akan tetapi proses yang terjadi memerlukan waktu yang lama..

Keuntungan penggunaan asap cair menurut Maga (1987) (11) antara lain lebih intensif dalam pemberian citarasa, kontrol hilangnya citarasa lebih mudah, dapat diaplikasikan pada berbagai jenis bahan pangan, lebih hemat dalam pemakaian kayu sebagai bahan asap, polusi lingkungan dapat diperkecil dan dapat diaplikasikan ke dalam bahan dengan berbagai cara seperti penyemprotan, pencelupan, atau dicampur langsung ke dalam makanan. Girrard (1992) menulis bahwa senyawa yang mendukung sifat antibakteri dalam destilat asap cair adalah senyawa fenol dan asam(11). Asap cair memiliki banyak manfaat dan telah digunakan pada berbagai industri, antara lain:

\section{Industri pangan}

Asap cair ini mempunyai kegunaan yang sangat besar sebagai pemberi rasa dan aroma yang spesifik juga sebagai pengawet karena sifat antimikrobia dan antioksidannya. Dengan tersedianya asap cair maka proses pengasapan tradisional dengan menggunakan asap secara langsung yang mengandung banyak kelemahan seperti pencemaran lingkungan, proses tidak dapat dikendalikan, kualitas yang tidak konsisten serta timbulnya bahaya kebakaran, yang semuanya tersebut dapat dihindari.

\section{Industri perkebunan}

Asap cair dapt digunakan sebagai koagulan lateks dengan sifat fungsional asap cair seperti antijamur, antibakteri dan antioksidan tersebut dapat memperbaiki kualitas produk karet yang dihasilkan.

\section{Industri kayu}

Kayu yang diolesi dengan asap cair mempunyai ketahanan terhadap serangan rayap daripada kayu yang tanpa diolesi asap cair (11).

\section{Alat-alat Pengolahan Asap Cair Reaktor Pirolisis \\ Reaktor pirolisis adalah alat pengurai senyawa-senyawa organik yang dilakukan dengan proses pemanasan tanpa berhubungan langsung dengan udara luar dengan suhu $400-600{ }^{\circ} \mathrm{C}$. Reaktor pirolisis dibalut dengan selimut dari bata dan tanah untuk menghindari panas keluar berlebih, memakai bahan bakar kompor minyak tanah, kemudian dilengkapi dengan alat penangkap ter dan seperangkat alat kondensasi. Proses}


pirolisis menghasilkan zat dalam tiga bentuk yaitu padat, gas dan cairan.

Cara penggunaan alat ini yaitu dengan memasukkan sampel ke dalam reaktor pirolisis dan ditutup rapat. Reaktor kemudian dipanaskan selama 5 jam. Destilat yang keluar dari reaktor ditampung dalam dua wadah. Wadah pertama untuk menampung fraksi berat, sedangkan wadah kedua untuk menampung fraksi ringan. Fraksi ringan ini diperoleh setelah dilewatkan tungku pendingin yang dilengkapi pipa berbentuk spiral.

\section{Destilator}

Destilator adalah alat yang berfungsi sebagai proses destilasi dengan tujuan memisahkan komponen dalam campuran berdasarkan perbedaan titik didihnya, atau pemisahan campuran berbentuk cairan atas komponennya dengan proses penguapan dan pengembunan sehingga diperoleh destilat dengan komponenkomponen yang hampir murni.

Destilasi adalah suatu proses pemisahan suatu komponen dari suatu campuran dengan menggunakan dasar bahwa beberapa komponen dapat menguap lebih cepat daripada komponen yang lainnya. Ketika uap diproduksi dari campuran, uap tersebut lebih banyak berisi komponenkomponen yang bersifat lebih volatil, sehingga proses pemisahan komponenkomponen dari campuran dapat terjadi.

$$
\text { Destilasi sederhana dilakukan }
$$
secara bertahap, sejumlah campuran dimasukkan ke dalam sebuah bejana, dipanaskan bertahap dan dipertahankan selalu berada dalam tahap pendidihan kemudian uap yang terbentuk dikondensasikan dan ditampung dalam labu erlenmeyer. Produk destilat yang pertama kali tertampung mempunyai kadar komponen yang lebih ringan dibandingkan destilat yang lain.

\section{BEBERAPA TEKNIK PEMBUATAN KOPRA DAN ARANG TEMPURUNG}

Teknik pengolahan kopra yang dipraktekkan secara turun temurun di wilayah ini adalah dengan tungku kopra asap metode bak terbuka (Gambar 1). Teknik pengolahan demikian menyebabkan asap dari bahan bakar (sabut kelapa, tempurung kelapa, atau kayu bakar) biasanya menyebar ke segala arah tergantung arah angin. Kopra asap yang dihasilkan biasanya berkualitas rendah antara lain ditandai oleh kandungan asap yang berlebihan, gosong, kadar air tinggi, berjamur, dan kotor. Disamping itu, teknik pengasapan menyebabkan terjadinya pencemaran lingkungan dan juga berdampak pada kesehatan pekerja karena terpapar pada asap secara berlebihan. Namun demikian, teknik ini terus dipraktekkan karena harga tungku yang murah dan terjangkau serta dapat dibuat secara mandiri oleh petani menggunakan material bangunan yang tersedia secara lokal/di lokasi perkebunan kelapa. Disamping itu, walaupun kopra yang dihasilkan berkualitas rendah namun tetap terjual walaupun dengan harga relatif rendah dari waktu ke waktu. 


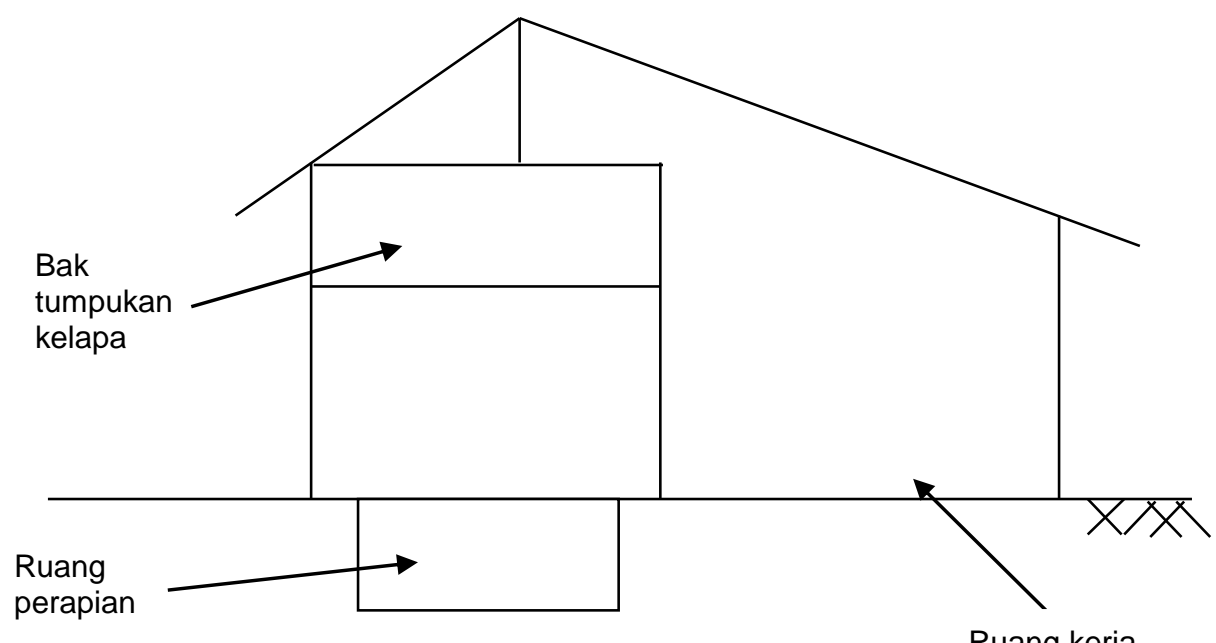

Ruang kerja

Gambar 1. Diagram skematik tungku kopra asap

Untuk menghasilkan kopra yang berkualitas tinggi, telah dilakukan introduksi teknologi kopra putih sejak awal tahun 2000an, antara lain oleh Balai Riset dan Standardisasi Industri Manado. Salah satu teknik pembuatan kopra putih yang diintroduksi adalah dengan menggunakan heater dari cast iron. Pada prinsipnya teknik tersebut merupakan modifikasi dari teknik pembuatan kopra asap, yaitu menggunakan bak sistem terbuka tapi dengan menggunakan heater dari cast iron (sistem pindah panas tertutup) sehingga asap dari bahan bakar yang terbentuk dapat dikeluarkan melalui cerobong asap dan tidak kontak langsung dengan kelapa yang dikeringkan (Gambar 2) (12).

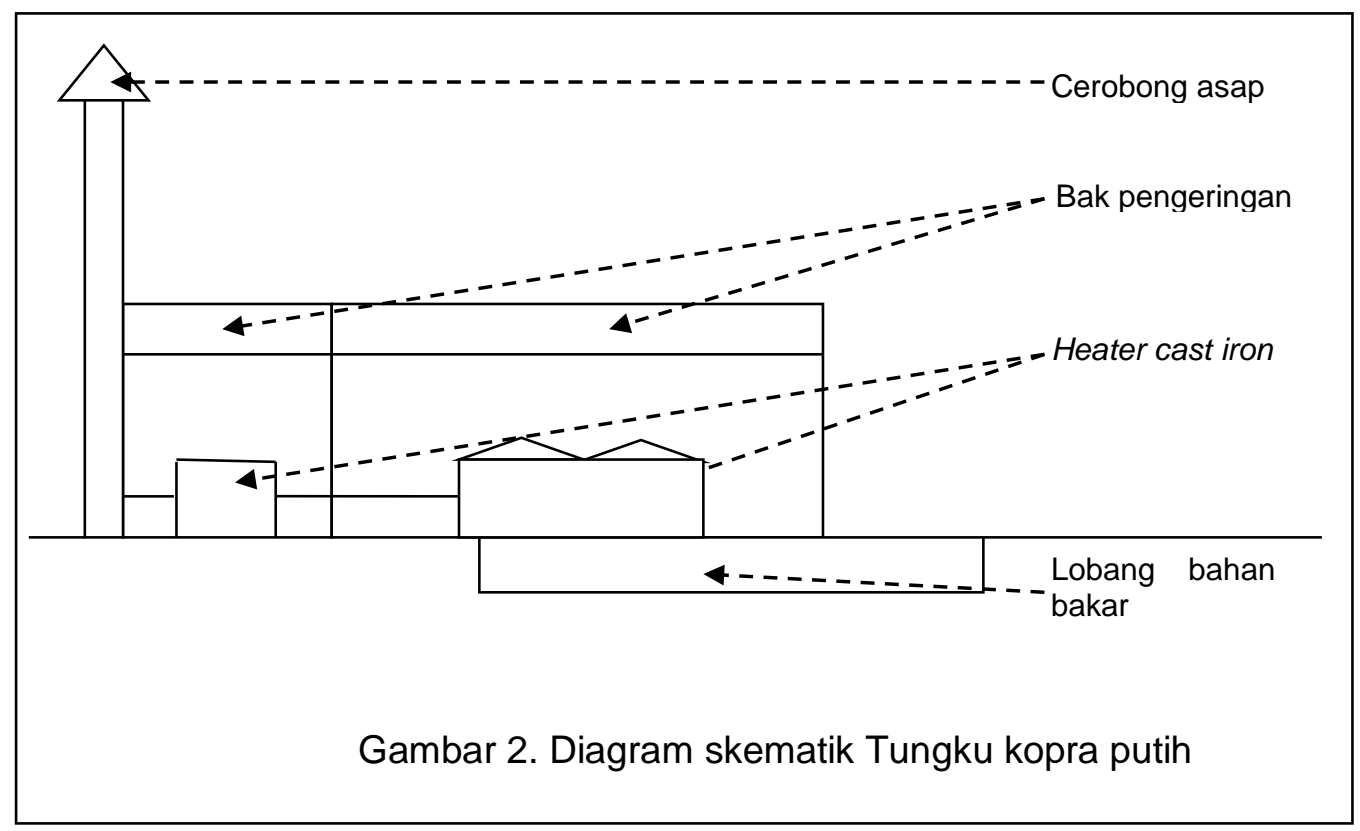


Secara teknis pembuatan kopra putih dengan mudah dapat dilakukan namun terkendala oleh mahalnya biaya pembuatan tungku kopra putih karena adanya komponen heater dari besi cor yang mahal demikian juga dinding-dinding tungku harus dibangun menggunakan adukan semen dan pasir serta menggunakan kolom cor yang diperkuat oleh besi beton sehingga sulit terjangkau oleh kebanyakan petani kelapa. Kendala ini dapat diatasi apabila harga kopra putih dapat ditingkatkan seiring dengan meningkatnya kuantitas kopra putih yang dihasilkan dan meningkatnya harga jual kopra putih. Untuk mencapai hal tersebut maka salah satu strategi yang dapat dilakukan adalah dengan merumuskan peraturan yang mengharuskan diproduksinya kopra berkualitas tinggi, yang identik dengan kopra putih, secara nasional. Namun demikian, selama peraturan tersebut tidak dibangun maka selama itu pula petani kelapa akan memproduksi kopra asap walaupun memiliki banyak kelemahan terutama dari segi kualitas, sebagaimana dibahas di atas.

Pengolahan tempurung kelapa menjadi arang tempurung dilakukan dengan beberapa cara. Cara yang sering dipraktekkan oleh petani kelapa/pengusaha arang tempurung adalah dengan metode pembakaran di dalam bak tanah. Sebagai pengembangan dari cara tradisional tersebut yang biasanya menghasilkan arang tempurung dengan kualitas yang kurang baik, telah dikembangkan tipe behive oleh Balai Riset dan Standardisasi Industri Manado (13). Kapasitas alat sekitar $6500 \mathrm{~kg}$ tempurung kelapa untuk sekali produksi dan menghasilkan arang tempurung yang berkualitas tinggi (Gambar 3).

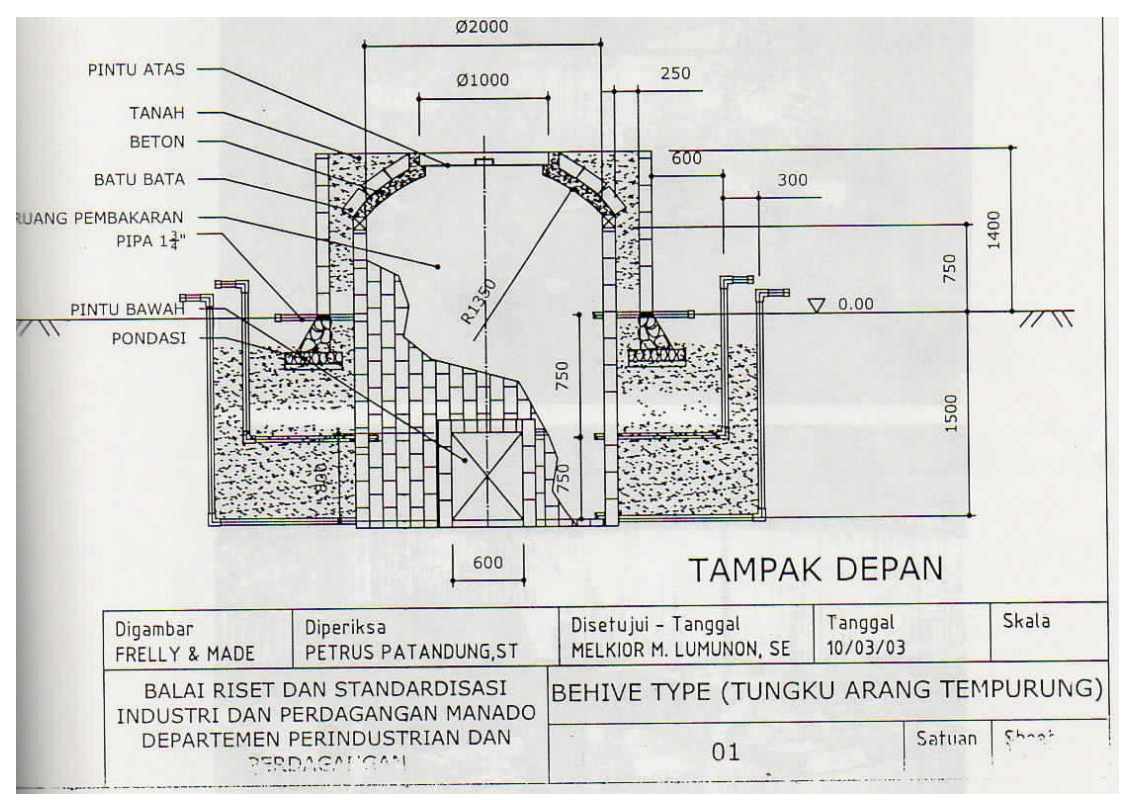

Gambar 3. Tungku pembuatan arang tempurung tipe behive 


\section{RANCANGAN TEKNIK AKUMULASI ASAP CAIR PENGOLAHAN KELAPA}

Akumulasi asap cair untuk tungku pembuatan kopra putih dengan heater cast iron maupun tungku pembuatan arang tempurung tipe behive dapat dilakukan dengan menambahkan kondensor menggunakan air sebagai pendingin pada cerobong asap/lobang pengeluaran asap. Penambahan komponen kondensor pada kedua alat membutuhkan pasokan air sebagai pendingin dan energi untuk sirkulasi air. Dengan demikian diperlukan adanya investasi untuk pengadaan air pendingin dan pompa air untuk sirkulasi air.

Pada prinsipnya tempat pengolahan keopra dan arang tempurung yang dilengkapi dengan kondensor tidak perlu dilakukan secara in-situ di lokasi perkebunan yang letaknya jauh, tapi di lokasi sekitar permukiman yang biasanya memiliki fasilitas pasokan energi listrik dan air. Pemilihan lokasi tersebut di atas dapat dilakukan mengingat pencemaran asap yang biasanya terjadi dapat dikendalikan dengan aplikasi kondensor tersebut di atas. Penempatan tungku di lokasi yang mudah dijangkau juga akan mengurangi biaya transportasi dan memudahkan pengawasan serta pengadaan bahan baku serta tenaga kerja.

Penambahan kondensor dan komponen pendukungnya akan meningkatkan biaya investasi dan operasional pengolahan kelapa dan arang tempurung. Sebagai alternatif dari rancangan teknik tersebut di atas, akumulasi asap cair kemungkinan dapat dilakukan dengan mengaplikasi teknik pendinginan seperti yang dipraktekkan pada pembuatan minuman tradisional Minahasa, yaitu pembuatan cap tikus.

Pada pembuatan cap tikus, nira aren dididihkan sehingga alkohol dari nira aren menguap. Uap panas selanjutkan dialirkan melalui sistem perpipaan yang terbuat dari bambu yang dirangkai sedemikian rupa dengan panjang sekitar 50 meter. Sistem tersebut memungkinkan berubahnya uap alkohol menjadi cairan alkohol. Penggunaan teknik ini pada pembuatan asap cair dari tungku kopra putih dan pembuatan arang tempurung tipe behive perlu dikaji melalui penelitian sehingga dapat dioperasionalkan dengan baik. Aplikasi teknik ini dapat mengurangi biaya investasi dan operasional pembuatan kopra asap atau kopra putih serta pembuatan arang tempurung sehingga lebih mudah diadopsi di tingkat pengolah kelapa dan hasil sampingnya.

\section{PENUTUP}

Terdapat potensi yang sangat besar dari asap cair pada pengolahan kelapa menjadi kopra asap atau kopra putih serta pembuatan arang tempurung. Akumulasi asap cair pada pengolahan kelapa dapat dilakukan dengan menambahkan kondensor pada tungku pembuatan kopra putih Tipe Baristand Industri Manado dan tungku pembuatan arang tempurung tipe Behive Baristand Industri Manado. Alternatif lainnya dari penggunaan kondensor tersebut adalah dengan meneliti kemungkinan aplikasi teknik 
pendinginan yang diterapkan pada proses pembuatan minuman tradisional Minahasa, yaitu pembuatan cap tikus. Akumulasi asap menjadi asap cair setidaknya memberikan dua keuntungan, yaitu meningkatkan nilai tambah pengolahan kelapa menjadi produk yang bermanfaat dan menghindarkan pencemaran lingkungan akibat asap dari pengolahan kopra dan pembakaran arang tempurung.

\section{DAFTAR PUSTAKA}

1. Ditjen Perkebunan. Statistik Perkebunan Kelapa 2014-2016 [Internet]. Jakarta; 2015. Available from: http://ditjenbun.pertanian.go.id/tinymc puk/gambar/file/statistik/2016/KELAP A 2014-2016.pdf

2. Rafie BT. Kurang kelapa, tata niaga diusulkan [Internet]. Kontan.co.id. [cited 2017 Jun 16]. Available from: http://industri.kontan.co.id/news/kuran g-kelapa-tata-niaga-diusulkan-1

3. Ruauw E, Baroleh J, Powa D. Kajian Pengelolaan Usahatani Kelapa di Desa Tolombukan Kecamatan Pasan Kabupaten Minahasa Tenggara. Agric Socioecon J [Internet]. 2011;7(2):3950. Available from: ejournal.unsrat.ac.id/index.php/article/ download/90/86.PDF.file

4. PARDI (Pacific Agribusiness Research and Development Initiative). Coconut Value Chain Review [Internet]. 2011 [cited 2017 Jun 15]. Available from: http://www.adelaide.edu.au/globalfood/documents/pardi-coconut-chainreview-nov-2011.pdf

5. Production of Coconuts in Whole Nuts 2010-2014 [Internet]. 2017. [cited
2017 Jun 15]. Available from: http://www.apccsec.org/apccsec/stati stic-11.html

6. Umpel W. Biaya pengolahan kopra di Sulawesi Utara. 2017.

7. Mahmud Zainal dan Ferry Yulius. Pusat Penelitian dan Pengembangan Perkebunan (Indonesian Center for Estate Crops and Development); Jalan Tentara Pelajar No.1 Bogor 16111. Prospek Pengolahan Hasil Samping Buah Kelapa Perspektif, 56 - Volume 4 Nomor 2, Desember $2005: 55$ - 63. Perspektif [Internet]. 2005;4(2):55-63. Available from: https://kelapaindonesia2020.wordpres s.com/makalah-tentangkelapa/zainal-mahmud-dan-yuliusferry/

8. Pojoh B. Desain peralatan aplikasi asap sabut kelapa bagi pengawetan bambu untuk substitusi besi beton. Manado; 2016.

9. Samadi M. Wawancara "Pembuatan arang tempurung secara terintegrasi." Manado; 2017.

10. Pojoh B. Pengawetan bambu dengan asap cair untuk substitusi besi beton rumah sederhana. Manado; 2016.

11. Darmadji P. "Teknologi Asap Cair dan Aplikasinya pada Pangan dan Hasil Pertanian." Pidato Pengukuhan Jabatan Guru Besar dalam Bidang Teknologi Pangan dan Hasil Pertanian [Internet]. DI. Yogyakarta; 2009. Available from: file://C:/Users/Fujitsu/Downloads/pid ato pengukuhan prof. dr. ir. e. purnama darmadji m.sc.pdf.

12. Pojoh B dkk. Pemasyarakatan teknologi pengolahan kopra putih. Manado; 2003. 
13. Patandung, Petrus D. Pemasyarakatan

modifikasi tungku "behive oven"

pembuatan arang tempurung.

Manado; 2003. 